\title{
Hypertension from Carotid Occlusion Decreases Renal Papillary Plasma Flow, Hypotension from Hemorrhage Increases It, an Autoregulatory Paradox
}

\author{
Mukul Ganguli, and Louis Tobian
}

\begin{abstract}
Renal papillary plasma flow was tested during acute increases and decreases of perfusion pressure using the ${ }^{125}$ I-labelled albumin technique. Increases of pressure were attained through ligation of carotid arteries; decreases of pressure through modest hemorrhage. In 12 control rats with blood pressure of $144 \mathrm{mmHg}$, the papillary plasma flow averaged $21.5 \mathrm{ml}$ per $100 \mathrm{~g}$ papilla per min. In 12 rats after ligation of carotid arteries, blood pressure rose from $143 \mathrm{mmHg}$ to 172 , a $20 \%$ increase. The papillary plasma flow in these rats with acute hypertension averaged $17.9 \mathrm{ml}$ per $100 \mathrm{~g}$ papilla per min, a $17 \%$ decrease $(p<0.025)$. In another 12 rats after bleeding $1 \%$ of body weight over a period of $10 \mathrm{~min}$, blood pressure dropped from $146 \mathrm{mmHg}$ to 104 , a $29 \%$ decrease. The papillary plasma flow in these rats with acute hypotension averaged $26.0 \mathrm{ml}$ per $100 \mathrm{~g}$ papilla per min, a $21 \%$ increase $(p<0.025)$. The decrease in papillary plasma flow during acute hypertension strongly suggests an increased vascular resistance of the descending vasa recta, while the increase in papillary plasma flow during acute hypotension suggests that vasodilatation occurred in these vessels. This dilatation may be produced by the local release of prostaglandins or other vasoactive substances. Thus, the renal papilla appears to "overshoot" its autoregulation of plasma flow, with actual reduced flow during an acute blood pressure rise and increased flow during an acute blood pressure fall, an enigmatic over-compensation. (Hypertens Res 1996; 19: 17-22)
\end{abstract}

Key Words: carotid ligation, hemorrhage, hypertension, hypotension, renal papillary autoregulation

Increased vascular resistance in the descending vasa recta is likely to be very important in the pathogenesis of experimental hypertension (1-3). Such increased resistance would decrease capillary pressure in the papilla and through Starling forces decrease the transudation of fluid out of the capillary lumens. This effect would decrease renal interstitial fluid pressure and thereby increase net $\mathrm{Na}$ reabsorption from the tubules. The resulting tendency to $\mathrm{Na}$ retention would encourage a rise in blood pressue (4).

There is an abundance of evidence that the blood flow to the kidney as a whole is usually autoregulated with great accuracy as perfusion pressure varies from $80-200 \mathrm{mmHg}(5-10)$. In chronic hypertensive rats, Goldblatt, Dahl and Kyoto spontaneous hypertension (SHR), total renal blood flow is similar to that observed in normotensive control animals, suggesting the presence of autoregulation even in the hypertensive kidneys $(6,11-13)$. The pressure flow relationship of the medullary circulation, however, has been studied by a few investigators, and the results are conflicting. Using a photo- electric technique, Kramer et al. (14) noted that the inner medullary blood flow was linearly related to the perfusion pressure, while the cortical blood flow exhibited a good autoregulation. Miyamoto and Gordon (15) noted that following a sudden rise in perfusion pressure, the medullary blood flow increased, while the cortical and total renal blood flow remained constant. Using laser-doppler flowmetry technique, Roman et al. (16) stated that in volume expanded rats papillary plasma flow is not autoregulated as well as total renal blood flow or cortical blood flow over the range of perfusion pressure from $100-150 \mathrm{mmHg}$. Stern et al. (17) using laser-doppler spectroscopy method and Cohen et al. (18) using erythrocyte velocity method, indicated that the medullary blood flow in the rat is autoregulated over a narrower range of arterial pressure than is whole kidney blood flow. We have studied renal papillary plasma flow in five different types of hypertension, including Post-salt, Goldblatt, DOCA, Dahl and Kyoto SHR hypertensions. All of our findings strongly suggest that the hypertensive papillae autoregulate their plasma flow in various

From the Renal and Hypertension Section, University of Minnesota Hospital and School of Medicine, Minneapolis 55455, MN, USA.

Address for Reprints: Mukul Ganguli, Ph. D., University of Minnesota Medical School, 2221 University Avenue, S. E., Suite 200, Minneapolis, Minnesota 55414, USA.

This work was supported by grants from the National Institute of Health (HL 17871) and the Cargill Foundation.

Received February 24, 1995; accepted in revised form August 11, 1995. 
types of long-standing hypertension. In fact, the hypertensive papillae have a plasma flow actually lower than normotensive kidneys despite the high inflow pressure $(1-3)$. It is not clear precisely why the hypertensive renal papillae have lower papillary plasma flow than the normotensive renal papillae. An increased vascular resistance in vessels supplying the papilla must be present and the rise in resistance is proportionately greater than the rise in arterial pressure. Our present studies were performed to further characterize the changes in renal papillary plasma flow that occur in response to acute increases and decreases of perfusion pressure.

\section{Methods}

Experiments were performed on male SpragueDawley rats (12 control rats, 12 rats with acute hypertension and 12 rats with acute hypotension) weighing between 300-350 g. Renal papillary plasma flow was measured with ${ }^{125}$ I-labelled albumin using our modification of the Lilienfield method (1, $2,19)$. Rats were anesthetized with inactin solution $100 \mathrm{mg} / \mathrm{kg}$ body weight i.p. The trachea, right jugular vein, left carotid artery and right femoral artery were cannulated. Direct femoral artery mean blood pressure was monitored continuously using a mercury manometer. The left kidney was approached through a flank incision and a loose knot was placed around the renal pedicle. Using a constant infusion pump, a solution of ${ }^{125} \mathrm{I}$-albumin $(4 \mathrm{uc} / \mathrm{ml})$ in $0.9 \%$ $\mathrm{NaCl}$ was infused into the jugular vein at the rate of $0.375 \mathrm{ml} / \mathrm{min}$. The accumulation of ${ }^{125}$ I-albumin in the renal papilla of adult rats increases linearly with time for about the first $36 \mathrm{~s}$ after the start of the infusion. Hence, an accumulation time of $24 \mathrm{~s}$ is well within the linear period and should provide an accurate index of plasma flow to the papilla. During the precise time interval in which radioactive albumin was entering the kidney, blood in the carotid artery was slowly and continuously sampled for radioactivity at approximately the same rate of blood withdrawl as fluid containing radioactive albumin entered the right atrium. After a time interval of $24 \mathrm{~s}$, the kidney pedicle was instantaneously ligated and the collection of blood from the carotid artery was terminated. The papilla was quickly dissected out and placed into airtight preweighed weighing bottle to obtain the wet weight of the papilla. After determining the wet weight, the tissue was heated at $80^{\circ} \mathrm{C}$ for $5 \mathrm{~min}$ to denature urease. Then, the radioactivity of the papilla was determined in a gamma scintillation counter. The samples of the blood from the carotid artery were similarly weighed and counted. Tissue radioactivity was expressed as counts per minute per gram of tissue. Plasma radioactivity was expressed as counts per minute per milliliter of plasma after corrections for the hematocrit. By dividing papillary radioactivity by plasma radioactivity, papillary plasma flow was determined, expressed in ml plasma flow per $100 \mathrm{~g}$ of papilla per min.

The tissue was then dried at $80^{\circ} \mathrm{C}$ for $48 \mathrm{~h}$ and then reweighed to find the water content. The tissue

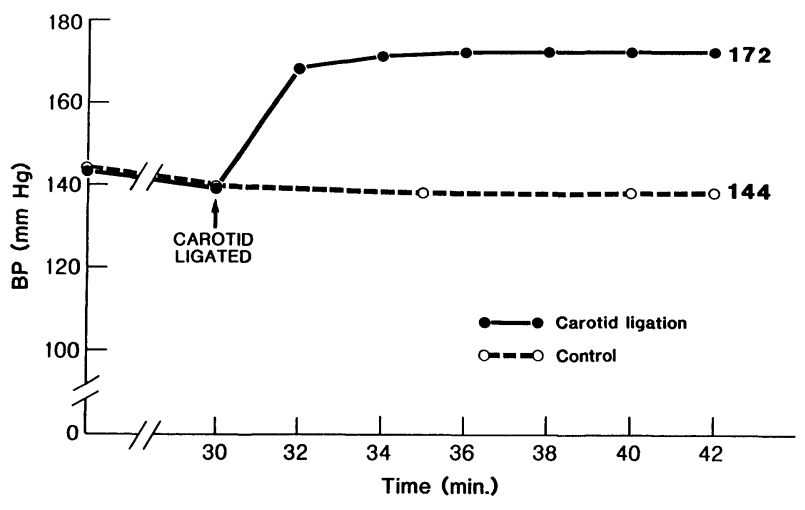

Fig. 1. Blood pressure changes in rats after bilateral carotid ligation.

was then extracted with water at $80^{\circ} \mathrm{C}$ for two hours to extract sodium and urea. The bottles were then cooled to room temperature and reweighed to determine the final volume of the water added for extraction. The supernatant after extraction was analyzed for sodium by flame photometry and urea by the method of Appleboom et al. (20).

In acute hypertension studies, an increase of blood pressure was obtained through ligation of the right carotid artery after a $30 \mathrm{~min}$ equilibration period. Renal papillary plasma flow was measured at $12 \mathrm{~min}$ after the start of the carotid ligation. In acute hypotension studies, a decrease of blood pressure was achieved through hemorrhage. After a 20 min equilibration period, rats were bled $1 \%$ of their body weight over a period of $10 \mathrm{~min}$. Twelve minutes after the start of the bleeding period, papillary plasma flow was measured in these rats. The renal papillary plasma flow of control rats was measured after $42 \mathrm{~min}$ of an equilibration period. Sodium and urea concentrations were measured in these very same papillas. Vascular resistance, aorta to papilla, is equal to the arterial pressure divided by the renal papillary plasma flow and expressed as $\mathrm{mmHg} / \mathrm{ml} .100 \mathrm{~g}$ papilla. min.

Data are presented as the mean \pm SEM and statistical analyses were carried out using student's $t$-test (21).

\section{Results}

Figure 1 shows the blood pressure changes after bilateral carotid ligation. The arrow represents the time of the second carotid ligation. The arterial pressure rose immediately from $144 \mathrm{mmHg}$ to 168 within a minute and remained elevated with a pressure of 172 for the next $12 \mathrm{~min}$. This was a $20 \%$ increase of blood pressure $(p<0.001)$. Table 1 shows the hematocrit, papillary plasma flow and vascular resistance from aorta to papilla after bilateral carotid ligation. The papillary plasma flow of 12 control rats averaged $21.5 \mathrm{ml}$ per $100 \mathrm{~g}$ papilla per minute, while the rats with acute hypertension after carotid ligation had a mean papillary plasma flow of 17.9 $\mathrm{ml}$ per $100 \mathrm{~g}$ papilla per minute. Thus on the aver- 
Table 1. Mean Hematocrit, Papillary Plasma Flow and Vascular Resistance after an Increase of Blood Pressure

\begin{tabular}{lccc}
\hline & $\begin{array}{c}\text { Hematocrit } \\
(\%)\end{array}$ & $\begin{array}{c}\text { Papillary } \\
\text { plasma flow } \\
(\mathrm{ml} .100 \mathrm{~g} . \mathrm{min})\end{array}$ & $\begin{array}{c}\text { Vascular } \\
\text { resistance, } \\
\text { aorta to papilla } \\
(\mathrm{mmHg} / \mathrm{ml} .100 \mathrm{~g} . \mathrm{min})\end{array}$ \\
\hline 12 Control rats (BP 144) & $47.0 \pm 0.5$ & $21.5 \pm 1.1$ & $6.6 \pm 0.4$ \\
12 Carotid ligation rats (BP 172) & $47.4 \pm 1.0$ & $17.9 \pm 0.9$ & $9.8 \pm 0.4$ \\
$p$ value & $\mathrm{NS}$ & $<0.025$ & $<0.001$ \\
\hline
\end{tabular}

(Mean \pm SEM)

Table 2. Mean Papillary Sodium and Urea Concentration after an Increase of Blood Pressure

\begin{tabular}{lcc}
\hline & $\begin{array}{c}\text { Papillary } \\
(\mathrm{mEq} / \mathrm{kg} \mathrm{H} \mathrm{O})\end{array}$ & $\begin{array}{c}\text { Papillary sodium } \\
\left(\mathrm{mmol} / \mathrm{kg} \mathrm{H} \mathrm{H}_{2} \mathrm{O}\right)\end{array}$ \\
\hline 12 Control rats (BP 144) & $150 \pm 4.7$ & $303 \pm 30$ \\
12 Carotid ligation rats (BP 172) & $132 \pm 4.8$ & $241 \pm 15$ \\
$p$ value & $<0.025$ & $<0.07$ \\
\hline
\end{tabular}

$($ Mean \pm SEM)

Table 3. Mean Hematocrit, Papillary Plasma Flow and Vascular Resistance after a Decrease of Blood Pressure

\begin{tabular}{|c|c|c|c|}
\hline & $\begin{array}{c}\text { Hematocrit } \\
(\%)\end{array}$ & $\begin{array}{c}\text { Papillary } \\
\text { plasma flow } \\
(\mathrm{ml} .100 \mathrm{~g} . \mathrm{min})\end{array}$ & $\begin{array}{c}\text { Vascular } \\
\text { resistance, } \\
\text { aorta to papilla } \\
(\mathrm{mmHg} / \mathrm{ml} .100 \mathrm{~g} . \mathrm{min})\end{array}$ \\
\hline 12 Control rats (BP 144) & $47.0 \pm 0.5$ & $21.5 \pm 1.1$ & $6.6 \pm 0.4$ \\
\hline 12 Rats after hemorrhage (BP 104) & $42.9 \pm 0.6$ & $26.0 \pm 1.4$ & $4.2 \pm 0.3$ \\
\hline$p$ value & $<0.001$ & $<0.025$ & $<0.001$ \\
\hline
\end{tabular}

(Mean \pm SEM)

age the hypertensive group had a $17 \%$ reduction in flow with a $p$ value of less than 0.025 . The vascular resistance, aorta to papilla, in the hypertensive group was increased by $48 \%$ above controls $(p<$ $0.001)$.

The sodium and urea concentrations of the papilla are presented in Table 2 . The control group averaged $150 \mathrm{mEq} \mathrm{Na} / \mathrm{kg}$ of papillary water, while the hypertensive group averaged $132 \mathrm{mEq} \mathrm{Na} / \mathrm{kg}$ of papillary water. The hypertensive group had a $12 \%$ reduction in papillary sodium concentration compared to normotensive controls with a $p$ value of less than 0.025 . There is also a $20 \%$ reduction of papillary urea concentration $303 \mathrm{vs}$. 241, mmol/kg of papillary water in the hypertensive group $(p<$ 0.07).

Figure 2 illustrates the blood pressure changes after modest hemorrhage. The time of bleeding is represented by the two arrows. Blood pressure dropped from $146 \mathrm{mmHg}$ to 98 during bleeding and remained constant for the next 12 min with a final pressure of 104 . Hemorrhage resulted in a $29 \%$ decrease in blood pressure $(p<0.001)$. The hematocrit, papillary plasma flow and vascular resistance, aorta to papilla after hemorrhage are shown in Table 3. The papillary plasma flow of 12 control rats averaged $21.5 \mathrm{ml}$ per $100 \mathrm{~g}$ papilla per min. The papillary plasma flow in 12 rats with hemorrhag-

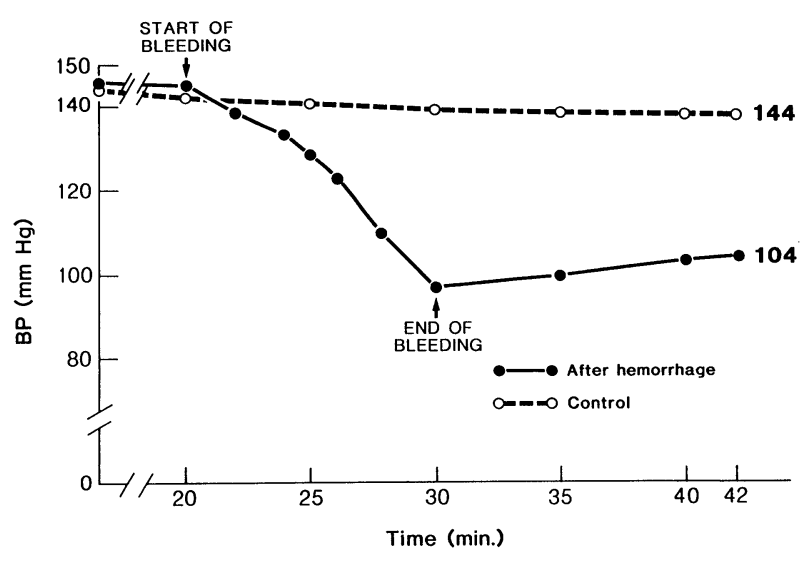

Fig. 2. Blood pressure changes in rats after modest hemorrhage.

ic hypotension averaged $26.0 \mathrm{ml}$ per $100 \mathrm{~g}$ papilla per min. Thus, on the average, the hypotensive group had a $21 \%$ increase in papillary plasma flow with a $p$ value of less than 0.025 . The vascular resistance, aorta to papilla, in the hypotensive group decreased by $36 \%$ compared to that of control group $(p<0.001)$. There was no significant change in papillary sodium between control rats and rats 
Table 4. Mean Papillary Sodium and Urea Concentration after a Decrease of Blood Pressure

\begin{tabular}{lcc}
\hline & $\begin{array}{c}\text { Papillary sodium } \\
\left(\mathrm{mEq} / \mathrm{kg} \mathrm{H} \mathrm{H}_{2} \mathrm{O}\right)\end{array}$ & $\begin{array}{c}\text { Papillary urea } \\
(\mathrm{mmol} / \mathrm{kg} \mathrm{H} \mathrm{O})\end{array}$ \\
\hline 12 Control rats (BP 144) & $150 \pm 4.7$ & $303 \pm 30$ \\
12 Rats after hemorrhage (BP 104) & $139 \pm 11.0$ & $144 \pm 15$ \\
$p$ value & $\mathrm{NS}$ & $<0.001$ \\
\hline
\end{tabular}

(Mean \pm SEM)

undergoing hemorrhagic hypotension (Table 4). But the papillary urea concentration was significantly lower in the hypotensive group, $303 \mathrm{vs} .144 \mathrm{mmol}$ per $\mathrm{kg}$ of papillary water $(p<0.001)$.

\section{Discussion}

These results indicate that the papilla in rats with acute hypertension after bilateral carotid ligation does not receive an elevated plasma flow even though the blood pressure is quite high. In fact the hypertensive papilla has a plasma flow actually lower than normal despite the high blood pressure. Conversely the papilla in rats with acute hypotension after hemorrhage does not receive a decreased plasma flow even though the blood pressure is quite low. In fact, the hypotensive papilla has a plasma flow actually higher than normal, despite the low blood pressure. Thus one can say that the renal papilla does appear to "overshoot" its autoregulation of plasma flow in both directions, with an actual reduced flow during an acute blood pressure rise and an actual increased flow during an acute blood pressure reduction. Stern et al. (17) observed papillary autoregulation in rats similar to that found in the cortex over a blood pressure range of $125-105 \mathrm{mmHg}$, and a linear decrement of flow at lower blood pressures. Cohen et al. (18) observed medullary autoregulation between $75-125 \mathrm{mmHg}$, whereas flow increased at even higher pressures. The low papillary flow indicates an unusual degree of increased vascular resistance in the descending vasa recta, more than is found in other vascular beds in hypertension. The renal medulla receives a very small fraction, $6 \%$ of the total renal blood flow, so a change in papillary plasma flow may not be reflected in the total renal blood flow. The total renal blood flow in Goldblatt, Dahl, Kyoto SHR and acute hypertension after bilateral carotid ligation is the same as that of their corresponding normotensive controls $(6,11-13,22)$. Thus it again shows that the resistance in vessels supplying the papilla is diproportionately higher than the vascular resistance of the kidney as a whole. In our present studies we observed a significant increase in vascular resistance, aorta to papilla, in the hypertensive group.

Hemorrhage resulted in a decrease in blood pressure and hemorrhagic hypotension caused an increase in renal papillary plasma flow and a decrease in aorta to papilla vascular resistance compared to the control group. Using radioactive microsphere technique, both McNay and Abe (23) and Lameire (24) have observed a significant increase in inner cortical blood flow and a significant decrease in outer cortical blood flow during reduction of renal artery pressure by aortic clamp in dog kidney. As blood entering the medulla must pass through the glomeruli of the inner cortex, blood flow to the inner cortex is an important determining factor of the medullary blood flow $(25,26)$. Using thermal washout techniques, both Tuttle and Sadler (27) and Grangsjo (28) also have observed an increase in outer medullary blood flow during reduction in renal perfusion pressure in dog kidney.

The increase in papillary plasma flow during an acute decrease in perfusion pressure strongly suggests a disproportionately strong vasodilation of the vessels supplying the papilla. This vasodilation may be produced by the local synthesis and release of prostaglandins or other vasoactive substances (29, 30 ). The papillary interstitial cells and the collecting duct cells are the main loci for prostaglandin synthesis in the renal medulla. After synthesis in the medulla, prostaglandins gain entry into the interstitial space and into the vasa recta and could thereby affect the caliber of the desending vasa recta of the outer medulla. The quick frozen outer medulla of the rat contains $\mathrm{PGE}_{2}, \mathrm{PGI}_{2}$, and $\mathrm{PGD}_{2}$, all considered to be vasodilator prostaglandins (31). Some cytochrome P450 metabolites of arachidonic acid have strong vasoactive properties and could be playing a role in the vascular resistance of the descending vasa recta $(32,33)$. Carriere et al. (34) noted that renal medullary blood flow in dog was well autoregulated after hemorrhagic hypotension, which may be in part the result of decreased hematocrit during hemorrhage, and the reduction of viscocity which may help to decrease resistance in the long vessels. In our study, the hemorrhagic hypotensive group had a significantly lower hematocrit than either the control or the acute hypertensive group. Using microscopic examination of the kidney sections after intravenous injection of carbon black particles, Carriere et al. (34) also revealed that vasodilatation of medullary vessels is present in hemorrhagic hypotension. This dilatation may be produced by local synthesis and release of prostaglandins or other vasoactive substances. In support of this, Chuang et al. (35) found a significant increase in papillary plasma flow in hydropenic rats with an exposed renal papilla. The administration of either of two prostaglandin synthesis inhibitors, indomethacin or meclofenamate, abolished the differences in papillary plasma flow between the control and exposed papillas. This study indicates that papillas undergo a vasodilation after exposure, which is mediated by a local increase of prostaglan- 
dins.

In the presence of blood loss, the overshoot of the autoregulation may represent the mechanism through which the body attempts to ensure at least some small amount of urine flow in the face of rapid hypotension. Complete cessation of urine flow would likely damage the tubules.

The renal papilla contains very high concentrations of sodium and urea as a result of countercurrent systems operating within this region of the kidney. It has been pointed out that changes in papillary blood flow may influence the papillary concentration of $\mathrm{Na}$ and urea, and thereby, the osmolal concentration of urine $(36,37)$. Our earlier studies indicate that there is significant reduction in papillary sodium and urea in Post-salt, Goldblatt, DOCA, and in sodium only in Kyoto SHR (3). The drop in papillary sodium in the chronic hypertensive rats cannot be ascribed to "wash out" of the countercurrent gradient for sodium because plasma flow to the hypertensive papillas was lower than to the normotensive papillas. The same general phenomenon of decreased papillary sodium and urea has also been noted in rats with acute hypertension. Acute hypertension induced by bilateral carotid ligation led to an increase in urine flow and to an increase in sodium excretion $(7,22)$. This increase in sodium excretion could be connected to the diminution of sodium in the papilla. The increased sodium excretion could be due to the pressure natriuresis phenomenon. In the isolated kidney study by Tobian et al. (38), more sodium was excreted for each increment of inflow pressure. Uhlich et al. (39) characterized $\mathrm{Na}$ transport in the mammalian collecting duct system as a bidirectional $\mathrm{Na}$ movement with efflux from the lumen generally exceeding the influx. The present finding could be explained by considering that the rate of $\mathrm{Na}$ influx into the lumen greatly exceeded the rate of efflux. According to Kunau and Lameire (22) the enhanced sodium excretion after an acute increase of perfusion pressure must be related to an inhibition of sodium absorption in the inner cortical nephrons or to an effect on sodium transport in the collecting system. There is no increase in sodium delivery from the superficial late distal tubule, since the fractional sodium delivery to the site is unaltered.

Acute decrease of perfusion pressure achieved by bleeding led to a significant decrease of papillary urea only, with no change in papillary sodium. The low urea may be due to passive "wash out" of urea due to high papillary plasma flow in the hypotensive group.

In conclusion, the renal papilla appears to "overshoot" its autoregulation of plasma flow, with an actual reduced flow during an acute hypertension and an actual increased flow during an acute hypotension. The explanation of this over-compensation of autoregulation in the renal papilla is still obscure.

\section{References}

1. Ganguli M, Tobian L: Does the kidney autoregulate papillary plasma flow in chronic "post-salt" hypertension? Am J Physiol 1974; 226: 330-333.

2. Ganguli M, Tobian L, Dahl L: Low renal papillary plasma flow in both Dahl and Kyoto rats with spontaneous hypertension. Circ Res 1976; 39: 337-341.

3. Ganguli M: Regulation of plasma flow and other functions of the renal papilla in hypertension. In Mandal, AK, Bohman S-O (eds): Plenum, New York, 1980, p.167-186.

4. Cowley AW Jr, Roman RJ, Fenoy FJ, Mattson DL: Effect of renal medullary circulation on arterial pressure. J Hypertens 1992; 10 (suppl 7): S187-S193.

5. Arendshorst WJ, Finn WF, Gottschalk CW: Autoregulation of blood flow in the rat kidney. Am J Physiol 1975; 228: 127-133.

6. Ben Ishay D, Knudsen KD, Dahl LK: Renal function studies in the early stages of salt hypertension in rats. Proc Soc Exp Biol Med 1967; 125: 515-518.

7. Heller J, Horacek V: Autoregulation of renal blood flow in the rat. Pflugers Arch 1977; 370: 81-85.

8. Hinshaw LB: Mechanism of renal autoregulation: role of tissue pressure and description of multifactor hypothesis. Circ Res 1964; 15 (Suppl. I): 120-131.

9. Selkurt EE: The renal circulation. In: Handbook of Physiology. Circulation. Washington, D.C., Am Physiol Soc 1963, sect 2, vol II, chapt 43, p. 1457-1516.

10. Thurau K: Renal hemodynamics. Am J Med 1964; 36: 698-719.

11. Arendshorst WJ, Beierwaltes WH: Renal and nephron hemodynamics in spontaneously hypertensive rats. Am J Physiol 1979; 236: F246-F251.

12. Grindt J, Ochwadt B: Durchblutung des Nierenmarkes, Gesamtnierendurchblutung and corticomedullare Gradienten beim experimentellen renalen Hochdruck der Ratte. Pfluegers Arch 1969; 313: 30-42.

13. Nishiyama K, Nishiyama A, Frohlich ED: Regional blood flow in normotensive and spontaneously hypertensive rats. Am J Physiol 1978; 230: 691-698.

14. Kramer K, Thurau D, Deetjen P: Hämodynamik des Nierenmarks. Capilläre Passagezeit, Blutvolumen, Durchblutung, Gewebshemätokrit und $\mathrm{O}_{2}$-Verbrauch des Nierenmarks in situ. Pflügers Arch Ges Physiol 1960; 270: 251-269.

15. Miyamoto J, Gordon S: The cortical and medullary blood flows of the isolated dog's kidney. Jpn J Physiol 1970; 20: 584-597.

16. Roman RJ, Cowley AW Jr, Garcia-Estan J, Lombard JH: Pressure diuresis in volume-expanded rats: cortical and medullary hemodynamics. Hypertension 1988; 12: 168-176.

17. Stern MD, Bowen PD, Parma R, Osgood RW, Bowman RL, Stein JH: Measurement of renal cortical and medullary blood flow by laser-doppler spectroscopy in the rat. Am J Physiol 1979; 236: F80-F87.

18. Cohen HJ, Marsh DW, Kayser B: Autoregulation in vasa recta of the rat kidney. Am J Physiol 1983; 245: F32-F40.

19. Lilienfield LS, Maganzini HG, Bauer MH: Blood flow in the renal medulla. Circ Res 1961; 9: 614-617.

20. Appleboom JW, Brodsky WA, Scott WN: Effect of osmotic diuresis on intrarenal solutes in diabetes insipidus and hydropenia.Am J Physiol 1965; 208: 38-45.

21. Snedecer GD, Cochran WG: Statistical Methods. Iowa State University Press, Ames, Iowa, 1967.

22. Kunau RT Jr, Lameire NH: The effect of an acute increase in renal perfusion pressure on sodium transport in the rat kidney. Circ Res 1976; 39: 689-695.

23. McNay JL, Abe Y: Pressure-dependant heterogeneity of renal cortical blood flow in dogs. Circ Res 1970; 
27: $571-587$.

24. Lameire N: Effect of autoregulation on the intracortical distribution of renal blood flow. Arch Int Physiol Biochem 1974; 82: 410-413.

25. Slotkoff LM, Logan A, Jose P, D'Avella, Eisner GM: Microsphere measurement of intrarenal circulation of the dog. Circ Res 1971; 28: 158-166.

26. Larsson C, Anggard E: Increased juxtamedullary blood flow on stimulation of intrarenal prostaglandin biosynthesis. J Pharmacol 1974; 25: 326-334.

27. Tuttle EP Jr, Sadler JH: Measurement of renal tissue fluid turnover rates by thermal washout techniques. In Rodbard S, Sapirstein LA, Wood JE III (eds): Hypertension, Proceedings of the American Heart Association, Council for High Blood Pressure Research, Cleveland 1964, New York, Am Heart Assoc 1965; 23: 3-16.

28. Grangsjo, G: Variations in the cortical and medullary blood flow through the dog kidney measured with heated thermocouples. Uppsala, Sweden, Academisk Maskinskrift, 1968.

29. Henrich WL, Anderson RJ, Burns AS, et al: The role of renal nerves and prostaglandins in control of renal hemodynamics and plasma renin activity during hypotensive hemorrhage in the dog. $J$ Clin Invest 1978; 61: 744-750.

30. Johnston PA, Selkurt EE: Effect of hemorrhagic shock on renal release of prostaglandin E. Am J Physiol 1976; 230: 831-838.

31. Tobian L, Uehara Y, Iwai J: Prostaglandin alterations in barely hypertensive Dahl S rats.Trans Assoc Am Physicians 1985; 97: 378-383.

32. Kauser K, Clark JE, Masters BS, et al: Inhibitors of cytochrome P-450 attenuate the myogenic response of dog renal arcuate arteries. Circ Res 1991; 68: 1154-1163.

33. Imig JD, Zou A-P, Ortiz de Montellano PR, Sui Z, Roman RJ: Cytochrome P-450 inhibitors alter afferent arteriolar responses to elevations in pressure. Am J Physiol 1994; 266: H1879-H1885.

34. Carriere S, Thorburn GD, O'Morchoe, Barger AC: Intrarenal distribution of blood flow in dogs during hemorrhagic hypotension. Circ Res 1966; 19: 167-179.

35. Chuang EL, Reineck HJ, Osgood RW, Kunau RT $\mathrm{Jr}$, Stein $\mathrm{JH}$ : Studies on the mechanism of reduced urinary osmolality after exposure of the renal papilla. $J$ Clin Invest 1978; 61: 633-639.

36. Berliner RW, Levinsky NG, Davidson DG, Eden M: Dilution and concentration of the urine and the action of antidiuretic hormone. Am J Med 1958; 24: 730-744.

37. Thurau K, Deetjen P, Kramer K: Hämodynamik des Nierenmarks. II Mitteilung. Wechselbeziehung zwischen väscularem und tubulärem Gegenstromsystem bei arteriellen Drucksteigerungen, Wasserdiurese und osmotiischer Diurese. Pflügers Arch Ges Physiol 1960; 270: 270-285.

38. Tobian L, Lange J, Azar S, et al: Reduction of natriuretic capacity and renin release in isolated bloodperfused kidneys of Dahl hypertension prone rats. Circ Res 1978; 43 (Suppl. I): 92-98.

39. Uhlich E, Baldamus CA, Ullrich $\mathrm{KJ}$ : Einfluss von Aldosteron auf den Natriumtransport in den Sammerlrohren der Säugertierniere. Pfluegers Arch 1969; 308: 111-126. 